\title{
14: $90790022-90769965$
}

National Cancer Institute

\section{Source}

National Cancer Institute. 14:90790022-90769965. NCI Thesaurus. Code C42411.

Physical location of GPR68_Gene 